\title{
Deep-Water Cartilaginous Fishes in the Central Mediterranean Sea: Comparison between Geographic Areas with Two Low Impact Tools for Sampling
}

\author{
Angela Carluccio ${ }^{1,2, *(\mathbb{D})}$, Francesca Capezzuto ${ }^{1,2}{ }^{(\mathbb{D}}$, Porzia Maiorano ${ }^{1,2}$, Letizia Sion ${ }^{1,2}$ \\ and Gianfranco D'Onghia ${ }^{1,2}$ D \\ 1 Department of Biology, University of Bari Aldo Moro, Via Orabona, 4-70125 Bari, Italy; \\ francesca.capezzuto@uniba.it (F.C.); porzia.maiorano@uniba.it (P.M.); letizia.sion@uniba.it (L.S.); \\ gianfranco.donghia@uniba.it (G.D.) \\ 2 CoNISMa, Piazzale Flaminio, 9-00196 Roma, Italy \\ * Correspondence: angela.carluccio@uniba.it
}

check for

updates

Citation: Carluccio, A.; Capezzuto,

F.; Maiorano, P.; Sion, L.; D'Onghia, G.

Deep-Water Cartilaginous Fishes in

the Central Mediterranean Sea:

Comparison between Geographic

Areas with Two Low Impact Tools for

Sampling. J. Mar. Sci. Eng. 2021, 9,

686. https://doi.org/10.3390/

jmse 9070686

Academic Editor: Alexei M. Orlov

Received: 14 May 2021

Accepted: 17 June 2021

Published: 22 June 2021

Publisher's Note: MDPI stays neutral with regard to jurisdictional claims in published maps and institutional affiliations.

Copyright: (c) 2021 by the authors. Licensee MDPI, Basel, Switzerland. This article is an open access article distributed under the terms and conditions of the Creative Commons Attribution (CC BY) license (https:// creativecommons.org/licenses/by/ $4.0 /$ )

\begin{abstract}
Baited lander represents a low impact technique, an alternative to the traditional trawl sampling for collecting data on fish diversity and abundance, especially for threatened species such as Chondrichthyes living in sensitive habitats. In this study, distribution and abundance of cartilaginous fish were compared between two geographic areas, the southern Adriatic Sea and the north-western Ionian Sea, with two low impact sampling gears, an experimental bottom longline and a baited lander. Species diversity was evaluated by applying ecological indices and difference in mean abundances were tested using multivariate analysis. A total of 13 species of cartilaginous fish were collected. Significant differences in the assemblage recorded in the same area using different sampling tools were detected and no significant differences were detected among different areas explored with the same method. Using longline, the most abundant species collected in both areas was Galeus melastomus, while using lander, the most observed species were Dalatias licha in the southern Adriatic Sea and Hexanchus griseus in the north-western Ionian Sea. According to IUCN classification, of the 13 species collected, 2 are near threatened and 5 are threatened. A better governance of sensitive habitats coinciding with the essential fish habitat for these species would ensure them a better conservation status.
\end{abstract}

Keywords: cartilaginous fish; baited lander; longline; Mediterranean Sea

\section{Introduction}

More than 1250 species of cartilaginous fish (sharks, rays, and chimaeras) are found throughout the world's oceans and some freshwater systems [1-3]. Sharks are one of the oldest extant radiations of vertebrate animals and they have evolved a wide range of morphological and mechanical features such as facultative parthenogenesis, embryonic diapause, bioluminescence, pockets, saws, hammers, stings, and electricity [2,4]. Sharks are usually near or at the top of the trophic chain, playing an important role in the structure and functioning of the marine ecosystem: they act as a link between food webs and across habitat aggregating, integrating, and transferring energy [2,5-8]. Cartilaginous fish are characterized by a suite of life history traits that lower their ability to tolerate anthropogenic impact $[6,9,10]$. In fact, chondrichthyans are generally characterized by slow growth, late maturity, low fecundity, long gestation periods, and a long-life span [9-11]. This strategy reduces the capacity to recover and, thereby, increases their vulnerability to human disturbances $[5,6,9,12]$.

A total of 88 chondrichthyes species have been recorded in the Mediterranean Sea, including 48 shark species, 38 batoid species, and 2 chimeras [1]. In this region, the spatial distribution and the abundance of various elasmobranch species have been mainly studied in the trawlable grounds through commercial and experimental trawl surveys [11,13-16]. 
Relative abundance estimates generated from scientific longline surveys have also been utilized in shark ecology studies, including those investigating declines in shark abundance, habitat use, and demographic population structure and variation in seasonal abundance [17-20]. Moreover, longline surveys allow the collection of samples for studies concerning genetics, diets, age, growth, reproduction, migration, and physiology [21-24]. Nevertheless, this sampling method might be not appropriate for threatened species: during longline surveys, indeed, sharks must be caught ad handled out of the water and the captured fishes are exposed to physiological stress and physical trauma that can induce pre- or post-release mortality [21,23-25].

Currently, baited remote underwater video surveys (BRUVS) have become an alternative approach for collecting data on larger-bodied and threatened species including sharks [26-32]. Baited lander represents a low impact non-extractive technique for collecting data on fish diversity, abundance, and behaviour, and can be used as an alternative method to the traditional trawl sampling: the passive nature of this method allows for its use in fragile and protected areas and when dealing with rare and threatened species that can be negatively affected by fishing gears [27-29,33-37].

The use of different sampling system has been validated through the comparison of species composition and abundance determined with different tools. Baited lander efficiency has been compared to those of different fishing methods including trap and longline $[21,27,38,39]$. These studies suggest that baited lander can provide information on species assemblage and abundance comparable to those generate with traps and longline. Additionally, the observations recorded with BRUVS and remotely operated vehicles (ROVs) have been compared to data collected with bottom beam trawls and prawn trawls, showing the difference in catch composition determined by the different fishing gear $[40,41]$.

The Mediterranean Sea is considered a hotspot of extinction risk for chondrichthyan species: in this basin, the chondrichthyes have suffered declines in abundance and biodiversity [16,42-44]. More than half of the assessed species (39 of 73 species recorded in the Mediterranean Sea) are regionally threatened. A total of 31 are most imperiled species and, among these, 20 are classified as critically endangered and 11 as endangered [42]. Moreover, the level of risk may be worse because uncertainty in species status is moderately high: of the 73 species assessed in the Mediterranean Sea, 13 remain data deficient $[10,16,42,43]$. The main threats that cartilaginous fishes have to endure are overexploitation both as targeted fisheries and incidental catch (by-catch), followed by habitat loss and degradation, pollution, and climate change [5,10,18,43-46].

In the last twenty years, sensitive habitats and marine vulnerable ecosystems (VMEs) have been explored with different low impact non extractive techniques as part of national and international projects carried out in the central Mediterranean ([47] and references therein). The aim of this study is to compare the distribution and abundance of cartilaginous fishes between two geographic areas of the central part of this basin, the southern Adriatic Sea and the north-western Ionian Sea, using two low impact sampling gears, an experimental longline and a baited lander.

\section{Materials and Methods}

\subsection{Area of Study}

The study area is located in the Central Mediterranean Sea along the Apulian margin between the southern Adriatic Sea and north-western Ionian Sea. This area is characterized by the presence of several morphological and geological structures that indent the continental shelf $[48,49]$. Along the Apulian margin, a belt of cold-water coral communities, probably connected by water mass flowing from the southern Adriatic to northern Ionian, has been identified [50-53]. 
The Bari canyon is a complex morphological structure indenting the southern Adriatic shelf in an west-east direction $[48,49,54]$. The Bari canyon hosts a diversified community of deep-water cnidarians characterized by the presence of Madrepora oculata and Lophelia pertusa together with Desmophyllum dianthus and Dendrophyllia cornigera, Leiopathes glaberrima associated with sponges, serpulids, and bryozoans $[34,35,53,55]$. The benthopelagic fauna distributed in the Bari canyon system is mainly represented by the teleost fishes Conger conger, Helicolenus dactylopterus, Merluccius merluccius, Phycis blennoides, and Pagellus bogaraveo, whereas Galeus melastomus is the most abundant cartilaginous fish [51,56]. In this area, recent explorations have revealed the existence of a new cold-water coral habitat southward to the Bari Canyon system in the area off Monopoli, where living colonies of M. oculata have been collected [51].

The north-western Ionian Sea is characterized by the presence of the Santa Maria di Leuca cold-water coral province, the widest and most studied cold-water coral ecosystem known in the Mediterranean [50,53,57]. Dead and living colonies of L. pertusa and M. oculata are widespread on an area of about $1000 \mathrm{~km}^{2}$ at a depth between 300 and $1110 \mathrm{~m}[50,58,59]$. The benthopelagic fauna associated with Santa Maria di Leuca cold-water coral province is characterized by the teleost fishes $C$. conger, $H$. dactylopterus, $M$. merluccius, $P$. bogaraveo, P. blennoides, and Polyprion americanus, which are targets of fishing activities carried out on the fishing ground surrounding the coral province $[60,61]$; moreover, the most abundant cartilaginous fish associated with this cold-water coral province is $G$. melastomus $[51,60,61]$.

\subsection{Survey Methodology}

Data were collected using two different tools, an experimental bottom longline and MEMO baited lander, in two geographic areas of the central Mediterranean, the southern Adriatic Sea and the north-western Ionian Sea (Figure 1, Table 1).

Table 1. Sampling data for each area and tools, with an indication of the depth range explored and number of deployments.

\begin{tabular}{ccccc}
\hline & \multicolumn{2}{c}{ Longline } & \multicolumn{2}{c}{ MEMO Lander } \\
\cline { 2 - 5 } & $\begin{array}{c}\text { Southern } \\
\text { Adriatic Sea }\end{array}$ & $\begin{array}{c}\text { North-Western } \\
\text { Ionian Sea }\end{array}$ & $\begin{array}{c}\text { Southern } \\
\text { Adriatic Sea }\end{array}$ & $\begin{array}{c}\text { North-Western } \\
\text { Ionian Sea }\end{array}$ \\
\hline Number of stations & 32 & 39 & 19 & 12 \\
Sampling hours (h) & 134 & 152.7 & 120 & 103 \\
Depth range (m) & $314-612$ & $418-635$ & $427-788$ & $547-792$ \\
\hline
\end{tabular}

Using longline, a total of 71 deployments were carried out for a total time of about 287 fishing hours (Table 1). A commercial fishing vessel was hired and equipped with a monofilament longline with 500 hooks and baited with Sardina pilchardus as bait (see details in [51]). The soak time lasted about $4 \mathrm{~h}$ on average. In order to make a comparison between the used tools, the abundance of the species collected in each deployment was standardized in number of individuals for hour of fishing on the seabed $(\mathrm{N} / \mathrm{h})$.

Using the MEMO baited lander, a total of 31 deployments were carried out between 427 and $792 \mathrm{~m}$, for a total time of $223 \mathrm{~h}$ of video record (Table 1). 


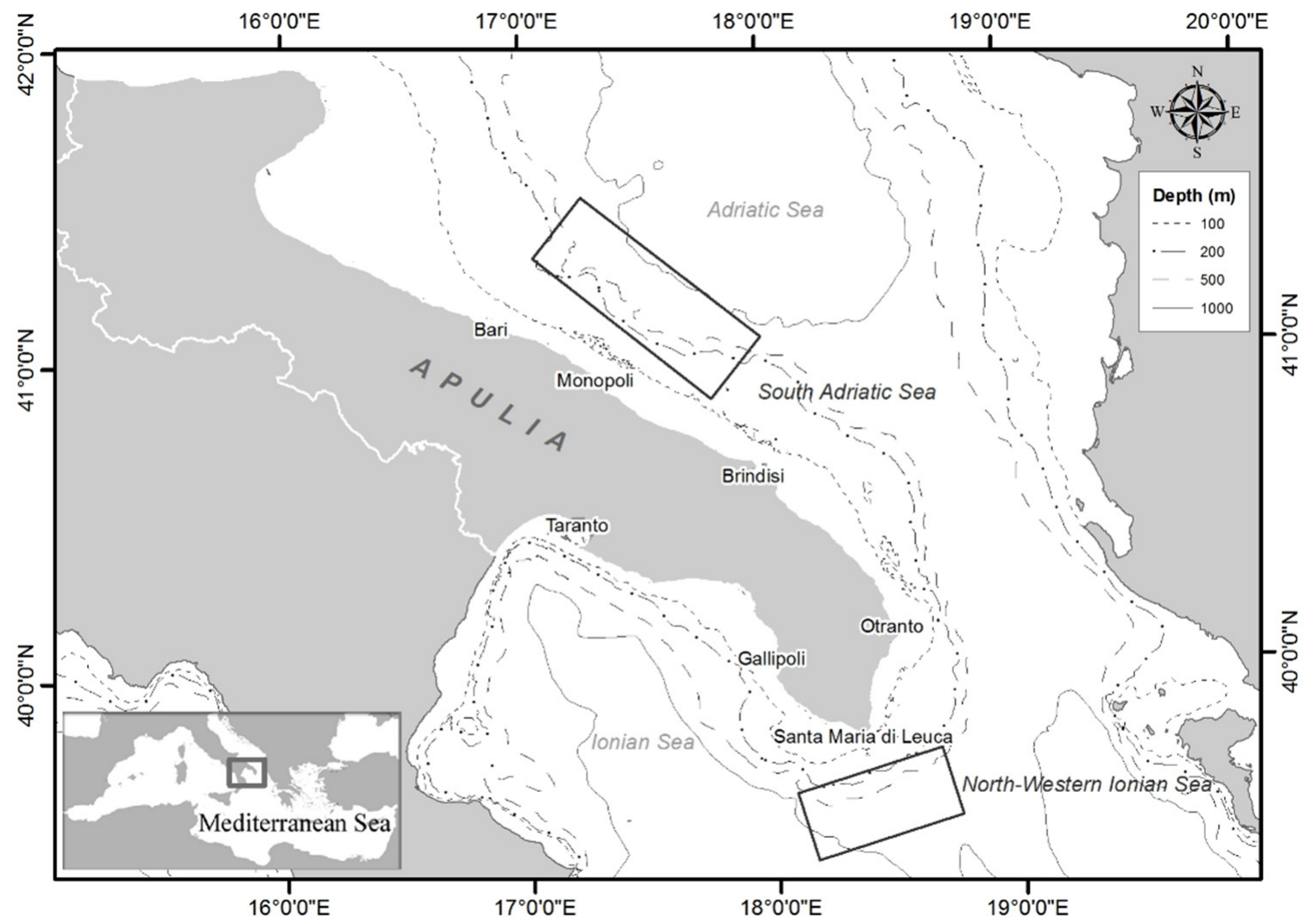

Figure 1. Map of the study area with an indication of the areas in which baited lander and longline were used.

The MEMO lander consists of a stainless steel frame (ø $2.15 \mathrm{~m} ; \mathrm{h} 1.65 \mathrm{~m})$ equipped with two video cameras (HD Multi SeaCam), two white LED lights, and a multiparametric probe (see details in [62]). A continuous connection is maintained via the acoustic modem with an onboard PC software platform, making images and sensor data available on the vessel. During each deployment, the lander was baited with a fresh specimen of Scomber scombrus. The bait produces an odour plume that attracts the animals in the field of video cameras. The videos recorded by both video cameras during each deployment were analysed using the Adobe Premier Pro software and the animals recorded by MEMO were identified to the lower taxonomical level using morphological characteristics. For each species, MaxN was recorded as the maximum number of individuals of the same species recorded at the same time in the field of the camera and MaxN per hour was used to standardize the abundance as $\mathrm{N} / \mathrm{h}$ for each deployment.

\subsection{Data Analysis}

The abundances for each species, for both longline and baited lander deployments, were standardized over the sampling time as number of individuals per hour $(\mathrm{N} / \mathrm{h})$. Species diversity was evaluated applying the Margalef species richness, Shannon-Wiener diversity, and Pielou's evenness ecological indices [63]. Cumulative curves were calculated through EstimateS 8.2 [64] in order to assess whether the number of sampling stations was sufficient to describe the species richness identified by the different tools. The slope (b) of the linear regression through the last five sub-samples was used, where $b \leq 0.05$ signified acceptable leveling off of the curve [65]. 
Non-metric multidimensional scaling (nMDS) ordination, based on a Bray-Curtis dissimilarity matrix, was applied to reveal multivariate patterns in the species assemblages [66]. Differences in mean abundances of species between the two explored areas and between longline and baited lander were tested using one-way analysis of similarities (ANOSIM, [66]) and one-way permutational multivariate analysis of variance (PERMANOVA, [67]); in both tests, a Bray-Curtis dissimilarity index was applied. Similarity percentage analysis (SIMPER) and indicator species analysis (IndVal) were used to determine which species are responsible for the dissimilarity among areas and sampling tools $[66,68]$. Statistical analyses were performed within PRIMER v6 with PERMANOVA add-on software and using the software PAST ver. 4.05 [69-71].

\section{Results}

A total of 13 species of cartilaginous fish were collected. In both areas, a total of 10 species were recorded (Table 2). In the southern Adriatic Sea, seven species were recorded using both MEMO lander and longline, whereas in the north-western Ionian Sea, five species were recorded using the lander and eight were collected by means of longline. Centrophorus granulosus and Etmopterus spinax were the only species collected in the two areas with both sampling tools. In both areas, G. melastomus was the most abundant species collected using longline. The greatest mean values observed using the lander were obtained for Dalatias licha and Hexanchus griseus in the southern Adriatic and north-western Ionian, respectively.

Table 2. Mean abundance $(\mathrm{N} / \mathrm{h})$ of cartilaginous fishes collected in the southern Adriatic and north-western Ionian Sea using longline and MEMO baited lander.

\begin{tabular}{|c|c|c|c|c|}
\hline \multirow[b]{2}{*}{ Species } & \multicolumn{2}{|c|}{ Longline } & \multicolumn{2}{|c|}{ MEMO Lander } \\
\hline & $\begin{array}{l}\text { Southern } \\
\text { Adriatic Sea }\end{array}$ & $\begin{array}{l}\text { North-Western } \\
\text { Ionian Sea }\end{array}$ & $\begin{array}{c}\text { Southern } \\
\text { Adriatic Sea }\end{array}$ & $\begin{array}{c}\text { North-Western } \\
\text { Ionian Sea }\end{array}$ \\
\hline Centrophorus granulosus (Bloch \& Schneider, 1801) & 0.01 & 0.04 & 0.08 & 0.01 \\
\hline Chimaera monstrosa Linnaeus, 1758 & 0.05 & & & \\
\hline Dalatias licha (Bonnaterre, 1788) & 0.01 & & 0.11 & 0.01 \\
\hline Dipturus oxyrinchus (Linnaeus, 1758) & & 0.02 & 0.01 & 0.03 \\
\hline Etmopterus spinax (Linnaeus, 1758) & 0.14 & 0.32 & 0.06 & 0.02 \\
\hline Galeus melastomus Rafinesque, 1810 & 3.78 & 4.03 & 0.10 & \\
\hline Hexanchus griseus (Bonnaterre, 1788) & & & 0.03 & 0.09 \\
\hline Leucoraja circularis (Couch, 1838) & & 0.02 & & \\
\hline Leucoraja fullonica (Linnaeus, 1758) & & 0.04 & & \\
\hline Prionace glauca (Linnaeus, 1758) & & 0.01 & & \\
\hline Pteroplatytrygon violacea (Bonaparte, 1832) & 0.03 & 0.07 & & \\
\hline Scyliorhinus canicula (Linnaeus, 1758) & 0.02 & & & \\
\hline Somniosus rostratus (Risso, 1827) & & & 0.01 & \\
\hline
\end{tabular}

The number of samples was sufficient to describe the species distribution in both areas and collected with different tools as the resulting cumulative curves reached the asymptote $(b \leq 0.05)$, although with different slope values (Figure 2). 


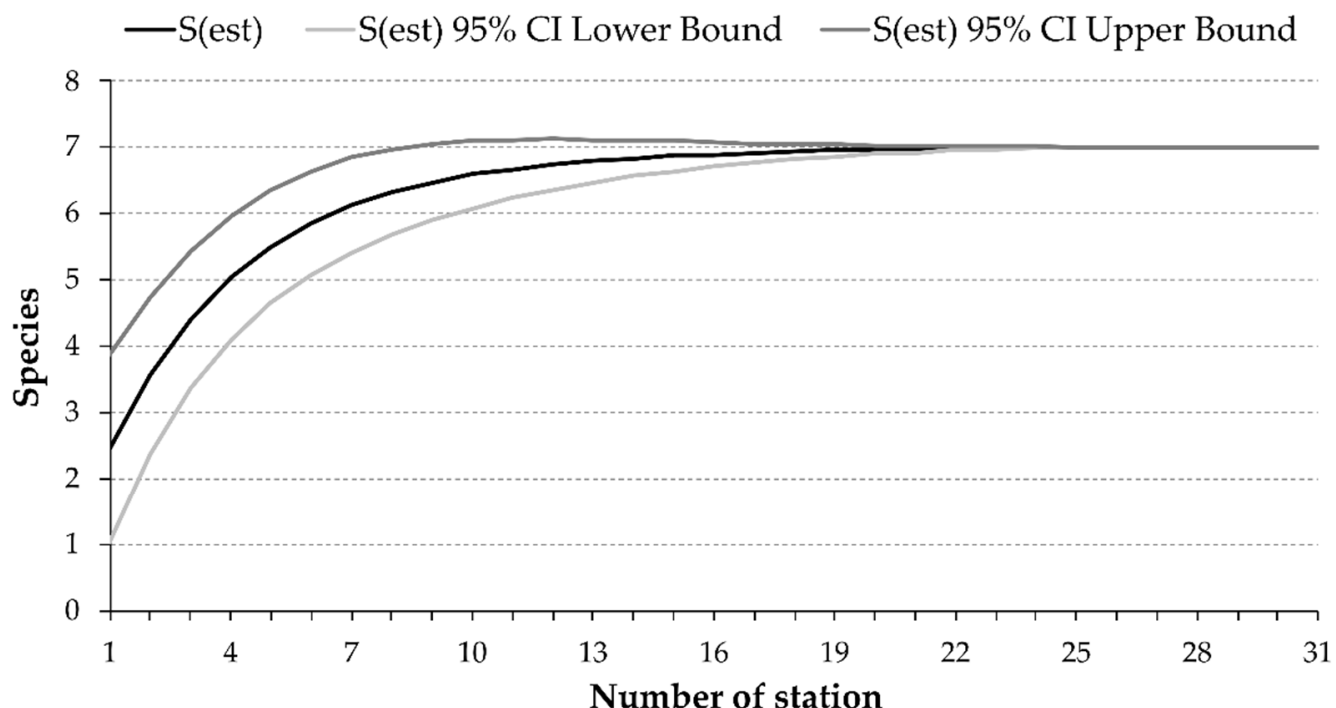

(a)

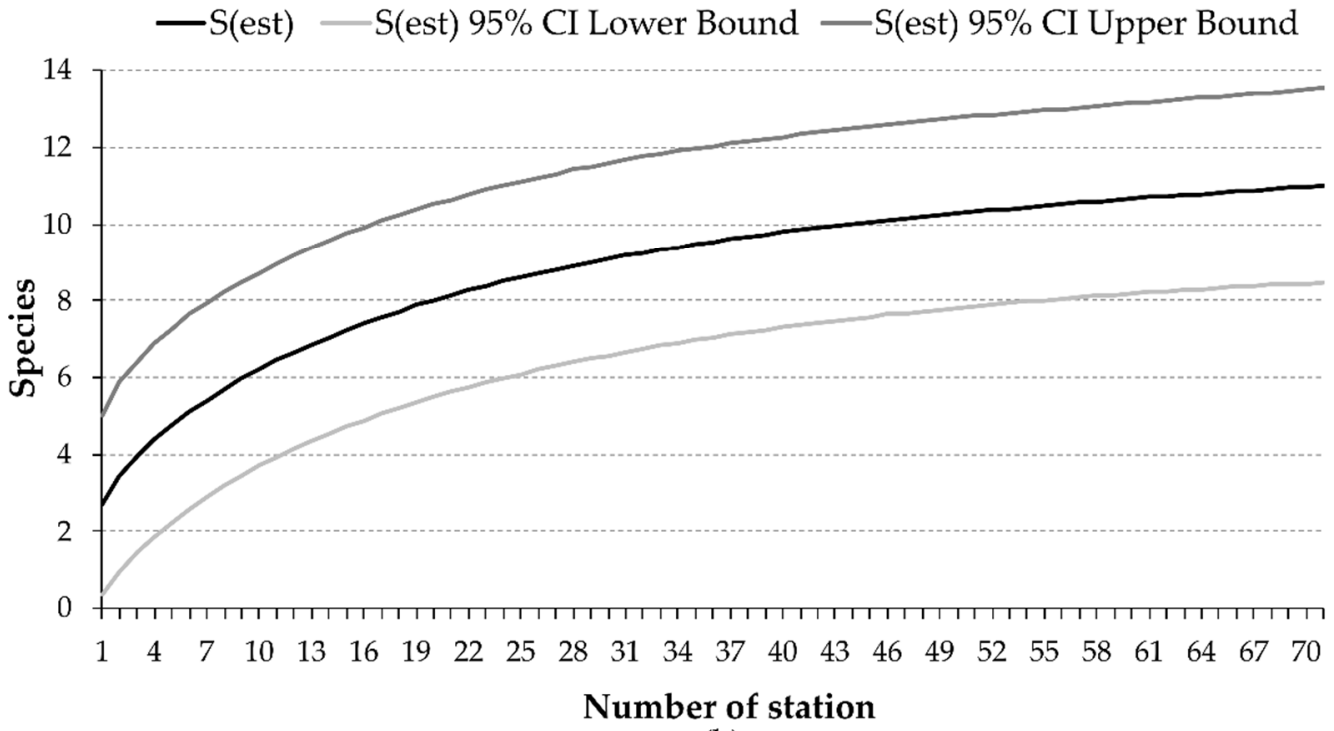

(b)

Figure 2. Cumulative curves for total deployments in the southern Adriatic Sea and north-western Ionian Sea using baited lander (a) and longline (b).

In each area, the values of ecological indices provided using the lander were greater than those obtained from longline. For the lander, the values were slightly greater in the southern Adriatic than in the north-western Ionian, while for the longline, it was the opposite (Table 3).

Table 3. Ecological indices computed in the southern Adriatic Sea and north-western Ionian Sea using longline and baited lander.

\begin{tabular}{ccccc}
\hline & \multicolumn{2}{c}{ Longline } & \multicolumn{2}{c}{ MEMO Lander } \\
\cline { 2 - 5 } & $\begin{array}{c}\text { Southern } \\
\text { Adriatic Sea }\end{array}$ & $\begin{array}{c}\text { North-Western } \\
\text { Ionian Sea }\end{array}$ & $\begin{array}{c}\text { Southern } \\
\text { Adriatic Sea }\end{array}$ & $\begin{array}{c}\text { North-Western } \\
\text { Ionian Sea }\end{array}$ \\
\hline Shannon-Wiener & 0.30 & 0.48 & 1.72 & 1.33 \\
Margalef & 0.96 & 1.08 & 1.61 & 1.52 \\
Pielou & 0.16 & 0.23 & 0.89 & 0.83 \\
\hline
\end{tabular}


A separation between the species assemblages recorded with longline and MEMO lander, with overlapping areas, was observed using nMDS (Figure 3).

This reflects the pattern showed by both ANOSIM and PERMANOVA, which detected significant differences in the assemblage recorded in the same area using different sampling tools, while no significant differences were detected among different areas explored with the same sampling tool (Table 4).

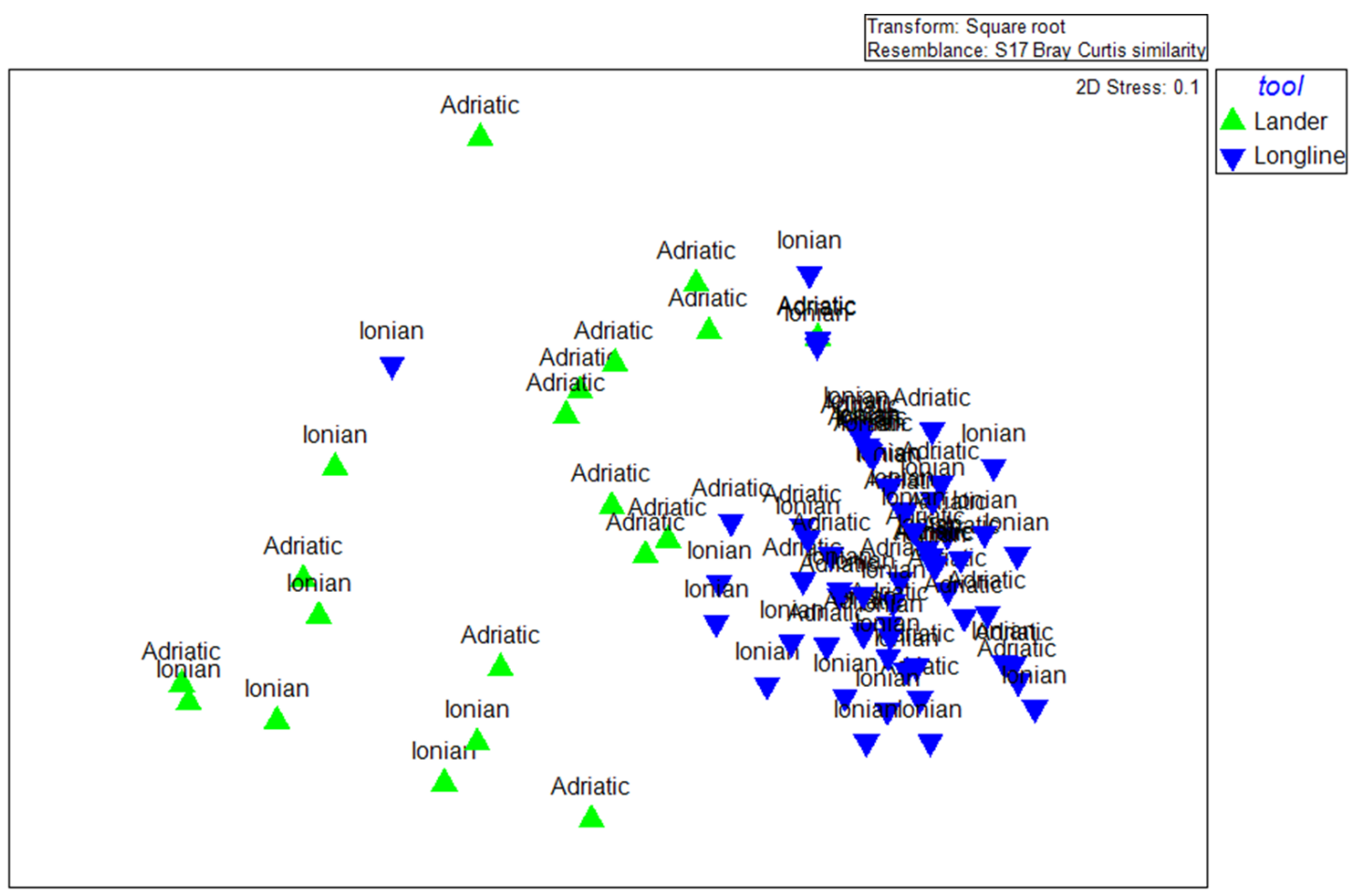

Figure 3. Non-metric multidimensional scaling (nMDS) plot of the abundance distinguishing among the areas and tools.

Table 4. Results of a permutational analysis of variance investigating the differences among the geographic areas and tools examined in this study, based on Bray-Curtis dissimilarity matrices of abundance indices of cartilaginous fish species. The table gives the degrees of freedom (df), the sums of squares (S), the mean squares (MS), the values of the pseudo-F statistics, the $p$-values, and the number of permutations (perms).

\begin{tabular}{cccccccc}
\hline & & df & S & MS & Pseudo-F & $p$-Value & Perms \\
\hline \multirow{3}{*}{ Tools } & Tools & 1 & 54721 & 54721 & 37475 & 0.001 & 997 \\
& Res & 83 & $1.212 \mathrm{e}+5$ & 1460.2 & & & \\
& Total & 84 & $1.7592 \mathrm{e}+5$ & & & & \\
& Area & 1 & 2334.2 & 2334.2 & 11.161 & & \\
& Area & Res & 83 & $1.7358 \mathrm{e}+5$ & 2091.4 & & \\
& Total & 84 & $1.7592 \mathrm{e}+5$ & & & \\
\hline
\end{tabular}

The SIMPER analysis found that the species G. melastomus and E. spinax contributed the most to the dissimilarity within groups (Table 5). The INDVal analysis showed that $G$. melastomus is representative for the assemblage sampled in the southern Adriatic and northwestern Ionian area using longline, whereas D. licha and H. griseus characterized the assemblage recorded using baited lander in the former and latter basin, respectively (Figure 4). 
Table 5. Results of similarity percentages analysis (SIMPER) of the differences in species composition between areas and sampling tools.

\begin{tabular}{cccc}
\hline Species & Av. dissim & Contrib. \% & Cumulative \% \\
\hline Galeus melastomus & 60.14 & 74.65 & 74.65 \\
Etmopterus spinax & 6.67 & 8.28 & 82.93 \\
Hexanchus griseus & 3.23 & 4.01 & 86.94 \\
Centrophorus granulosus & 3.18 & 3.94 & 90.88 \\
Dalatias licha & 2.89 & 3.59 & 94.47 \\
Pteroplatytrygon violacea & 1.30 & 1.61 & 96.08 \\
Dipturus oxyrinchus & 1.05 & 1.31 & 97.38 \\
Scyliorhinus canicula & 0.89 & 1.10 & 98.49 \\
Leucoraja fullonica & 0.43 & 0.53 & 99.02 \\
Chimaera monstrosa & 0.38 & 0.47 & 99.49 \\
Somniosus rostratus & 0.18 & 0.22 & 99.71 \\
Leucoraja circularis & 0.12 & 0.15 & 99.86 \\
Prionace glauca & 0.11 & 0.14 & 100.00 \\
\hline
\end{tabular}

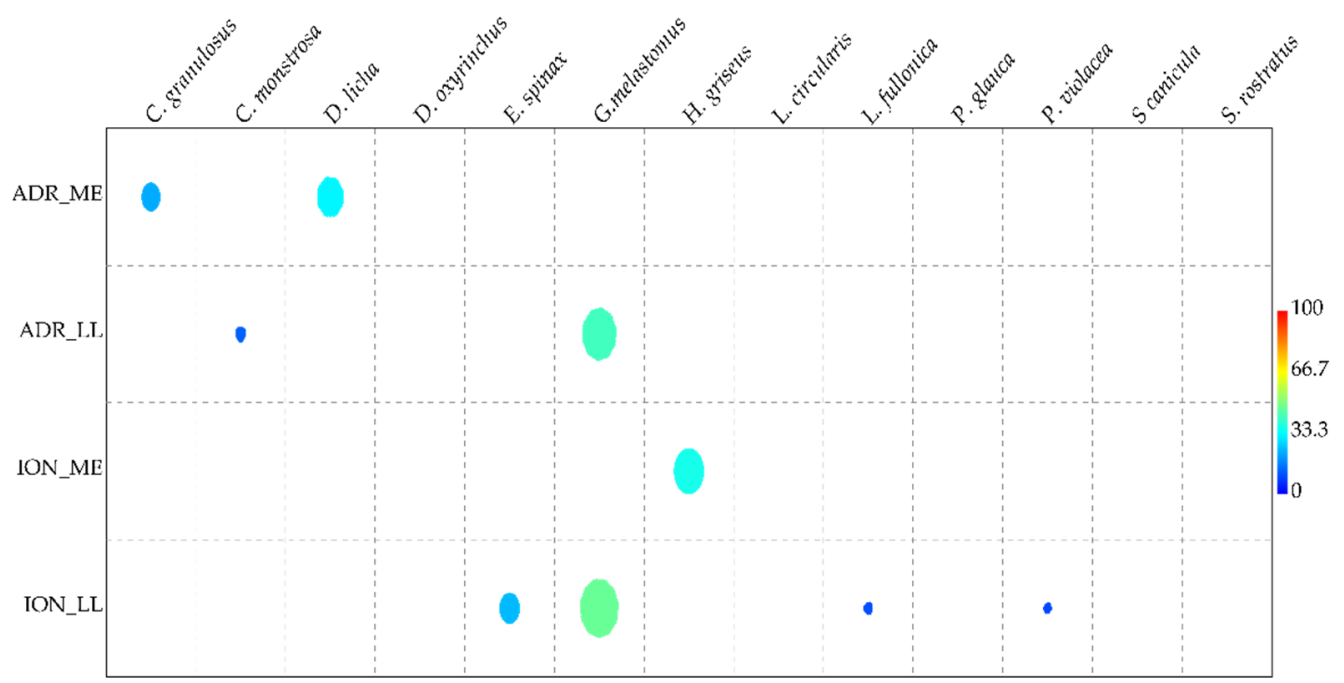

Figure 4. Indicator species analysis (IndVal) plot with representative species of Adriatic (ADR) and Ionian (ION) area and MEMO lander (ME) and longline (LL).

\section{Discussion}

The simultaneous application of two different low impact sampling tools allowed the collection of new information on abundance and distribution of deep-water cartilaginous fishes living in the southern Adriatic Sea and north-western Ionian Sea.

Using the longline, the most abundant species collected in both areas was G. melastomus (Table 2). Data on distribution and abundance of demersal chondrichthyans in the Mediterranean Sea collected during MEDITS bottom trawl surveys [72] during the period 2012-2015 showed that G. melastomus and E. spinax are the most abundant in both the southern Adriatic Sea and the north-western Ionian Sea [11]. The lower abundance of G. melastomus recorded with baited lander could be explained by its high visual acuity and sensibility to the light that can disturb the animal [73]. Using MEMO lander, the most observed species were D. licha and G. melastomus in the southern Adriatic Sea and H. griseus in the north-western Ionian Sea. This shark was never collected using longline in both areas. This can be explained by its ability to break hooks and longline snoods thanks to its body dimension and sharp teeth, as suggested by [29]. As a result, in the case of large bodied species, baited lander can be more efficient than longline in collecting information on abundance and distribution. In the course of MEDITS bottom trawl surveys carried out in the period 2012-2015 in north-western Ionian Sea, H. griseus was never sampled by trawl net [11], confirming the importance of the application of alternative low impact sampling 
tool. The higher abundance of $D$. licha recorded in the southern Adriatic Sea using baited lander can be explained by its feeding strategy and its limited scavenger behaviour that make this species less attracted by longlines: kitefin shark in fact feeds mainly on teleost fishes and small sharks such as G. melastomus and E. spinax [74].

In the southern Adriatic Sea, four of the seven collected species were sampled using both sampling tools, whereas in the north-western Ionian Sea, only three species were sampled using both baited lander and longline. ANOSIM and PERMANOVA showed significant differences in the assemblage recorded in the same area using different sampling tool, while no significant differences were detected among the two areas explored with the same method. This might be explained by the different selectivity of the techniques used in this study as well as by the homogeneity of the areas explored with longline and baited lander. The southern Adriatic Sea and north-western Ionian Sea are indeed connected by a complex deep-water circulation flowing along the Apulian margin and are both characterized by the presence of several geomorphological structures $[48,49,52,53]$. The differences in the species composition and abundance between the two sampling tools might be explained by their different selectivity in relation to species ecology and feeding habits. Moreover, the two techniques also differed in the type and quantity of bait used: each longline had 500 individual baits spreading a broad odour plume, whereas MEMO lander is a single baited system [21,29]. As baited lander is equipped with lights, differences in species composition might be also explained by physiological characteristics of the species involving the visual system.

The samples were sufficient to describe the species distribution sampled with two different tools, although differences in their efficiency have been detected by the cumulative curves. These results suggest good efficiency of baited lander to collect information on species diversity of cartilaginous fishes, adding information on the abundance of species that could not be collected with longline. Given the differences between the two sampling tools in their efficacy and the need for a different sampling effort, baited lander and longline should be used simultaneously to obtain a good level of information about the diversity of cartilaginous fishes with low or even zero impact on threatened species living in fragile habitats.

Baited lander is a low impact non-extractive sampling method for collecting data on fish abundance and its passive nature has become a fundamental aspect when targeting rare and threatened species that can be negatively affected by fishing gears and in the study of sensitive and vulnerable habitats, where other sampling tools would damage the benthic fauna and habitats unacceptably [28,33-36]. The application of baited lander could avoid biases owing to mesh or hook selectivity that affect the conventional extractive sampling method [21,28]. Moreover, videos generated by BRUVSs enable observation of specie behavior and interactions and, although the identification of species can in some cases be doubtful, they represent a permanent record that can be examined and checked by different observers, allowing impartial and repeatable data collection [28,34,38,62].

Experimental longlines with a small number of hooks seem to be the least harmful fishing gear, especially in a structurally complex habitat [38]. This cost-effective and relatively easy-to-use sampling method provides high quality data on species that could not be easily identified on video and allows the collection of tissue sample and the application of conventional and electronic tags [21,27]; moreover, longline can provide information on population biology, diet, reproduction, age, and growth [21-24].

Mediterranean Sea is considered a key hotspot of extinction risk for cartilaginous fish, with highest proportion of threatened species [42-44]. Of the 13 species sampled in this study, only 5 are classified by IUCN as least concern; 2 as near threatened (Chimaera monstrosa and Dipturus oxyrinchus); 5 as threatened (Dalatias licha is classified as Vulnerable and Prionace glauca, Leucoraja circularis, Leucoraja fullonica, and Centrophorus granulosus are classified as critically endangered); and 1 species, Somniosus rostratus, recorded exclusively with baited lander, is classified as data deficient. 
Conservation strategies depend on the available information on their distribution, biology, ecology, and abundance, as well as on the identification and protection of habitats that can act as spawning and nursery area for these species [1,16]. Although G. melastomus is a deep-water shark affected by commercial fishing, its higher level of abundance could be due to a deeper distribution than that of fishing and the availability of refuge areas not affected by this activity [75]. This may also be true for E. spinax, whose distribution is still deeper [14]. Although bathymetric distribution of C. granulosus and D. licha is quite comparable to those of G. melastomus and E. spinax [14], their abundances are lower because they might be more sensitive to fishing activities as top predators [76]. Data from MEDITS bottom trawl surveys carried out in the period 2012-2015 confirm their different abundances. The frequencies of occurrence in both areas were greater than $70 \%$ and $60 \%$ for G. melastomus and E. spinax, respectively, whereas they were $11.1 \%$ in the southern Adriatic Sea and 7.6\% in the north-western Ionian Sea for D. licha and less than $1 \%$ in both areas for C. granulosus [11]. Female of the latter species has low fecundity with only one embryo and a reproductive cycle that could last two years, making this species particularly vulnerable to human impact $[77,78]$. The highest resilience shown by G. melastomus could be explained not only by its wide distribution, but also by its reproductive traits (i.e., egg deposition occurring throughout the year and deposition of multiple egg case) and its feeding strategy $[16,75,79,80]$. G. melastomus, in fact, is an opportunistic meso-predator and scavenger or generalist feeder with a broad spectrum of pray; it is capable of adapting its diet to seasonal fluctuations of pray and taking advantage of discarded material from fishing activities $[16,76,80]$. During the MEDITS trawl surveys carried out from 2012 to 2015, the frequency of occurrence recorded for L. circularis was 8.3\% in the southern Adriatic Sea and $1.7 \%$ in the north-western Ionian Sea, whereas, in the same period, L. fullonica was never collected in both areas [11]. The batoid species, such as L. circularis and L. fullonica, are particularly vulnerable to bottom trawling as bycatch owing to their strictly benthic habitus. Moreover, the recovery of their population is hindered by the limited capacity of skates to realize seasonal movements owing to their philopatric behaviour [81,82].

When a species has a bathymetric distribution that overlaps with that of fishing, its conservation status also depends on the availability of refuge areas in the same depth range. Cold-water coral areas are characterized by the presence of three-dimensional complex habitats, which represent a refuge for several vertebrate and invertebrate species that use this habitat for shelter, feeding, spawning, and as nursery areas, thus providing an essential fish habitat (EFH) for species harvested by fishing activities carried out on the muddy bottoms surrounding cold-water coral areas $[47,51,83]$.

Cold-water coral habitats are also included on the list of vulnerable marine ecosystems (VMEs) for which conservation constitutes a global priority (FAO 2009). A fisheries restricted area (FRA), in which towed dredges and bottom trawl nets have been prohibited, has been established for the Santa Maria di Leuca cold-water coral province in 2006 [84]. Currently, negotiations are ongoing for the implementation of a FRA in the Bari Canyon system [85] that would ensure a better governance of the Apulian cold-water coral ecosystems and thus a better conservation status of cartilaginous species that use this habitat.

Author Contributions: Conceptualization, A.C., G.D. and P.M.; methodology, A.C. and F.C.; formal analysis, A.C. and F.C.; investigation, G.D., P.M., L.S., F.C. and A.C.; writing-original draft preparation, A.C.; writing-review and editing, G.D., P.M., L.S. and F.C.; supervision, G.D. All authors have read and agreed to the published version of the manuscript.

Funding: This research was funded by EU_7FP CoralFISH project, OBAMA_PRIN and RITMARE projects funded by the Italian Ministry of University and Research (MIUR), and Marine Strategy Framework Directive monitoring project funded by the Italian Ministry of the Environment (MATTM).

Institutional Review Board Statement: Ethical review and approval were not necessary for this study because all animals sampled were already dead when arriving on board. Therefore, the scientific activity in the context of this study is not subject to the European Commission recommendations (Directive 2010/63/EU of the European Parliament and of the Council of 22 September 2010) or to 
Italian National Law (Decree Law No. 26 of 4 March 2014) regarding the protection of animals used for scientific experiments.

Data Availability Statement: The data presented in this study are available on request from the corresponding author.

Conflicts of Interest: The authors declare no conflict of interest.

\section{References}

1. Serena, F.; Abella, A.J.; Bargnesi, F.; Barone, M.; Colloca, F.; Ferretti, F.; Fiorentino, F.; Jenrette, J.; Moro, S. Species diversity, taxonomy and distribution of chondrichthyes in the Mediterranean and Black Sea. Eur. Zool. J. 2020, 87, 497-536. [CrossRef]

2. Dulvy, N.K.; Simpfendorfer, C.A.; Davidson, L.N.K.; Fordham, S.V.; Bräutigam, A.; Sant, G.; Welch, D.J. Challenges and priorities in shark and ray conservation. Curr. Biol. 2017, 27, R565-R572. [CrossRef] [PubMed]

3. Weigmann, S. Annotated checklist of the living sharks, batoids and chimaeras (Chondrichthyes) of the world, with a focus on biogeographical diversity. J. Fish Biol. 2016, 88, 837-1037. [CrossRef]

4. Fields, A.; Feldheim, K.A.; Poulakis, G.R.; Chapman, D.D. Facultative parthenogenesis in a critically endangered wild vertebrate. Curr. Biol. 2015, 25, R439-R447. [CrossRef] [PubMed]

5. Ferretti, F.; Myers, R.A.; Serena, F.; Lotze, H.K. Loss of large predatory sharks from the Mediterranean Sea. Conserv. Biol. 2008, 22, 952-964. [CrossRef] [PubMed]

6. Stevens, J.D.; Bonfil, R.; Dulvy, N.K.; Walker, P.A. The effects of fishing on sharks, rays, and chimaeras (chondrichthyans), and the implications for marine ecosystems. ICES J. Mar. Sci. 2000, 57, 476-494. [CrossRef]

7. Cortes, E. Standardized diet compositions and trophic levels of sharks. ICES J. Mar. Sci. 1999, 56, 707-717. [CrossRef]

8. Heupel, M.R.; Knip, D.M.; Simpfendorfer, C.A.; Dulvy, N.K. Sizing up the ecological role of sharks as predators. Mar. Ecol. Prog. Ser. 2014, 495, 291-298. [CrossRef]

9. Rigby, C.; Simpfendorfer, C.A. Patterns in life history traits of deep-water chondrichthyans. Deep Sea Res. Part II Top. Stud. Oceanogr. 2015, 115, 30-40. [CrossRef]

10. Peristeraki, P.; Tserpes, G.; Kavadas, S.; Kallianiotis, A.; Stergiou, K.I. The Effect of bottom trawl fishery on biomass variations of demersal chondrichthyes in the eastern Mediterranean. Fish. Res. 2020, 221, 105367. [CrossRef]

11. Follesa, M.C.; Marongiu, M.F.; Zupa, W.; Bellodi, A.; Cau, A.; Cannas, R.; Colloca, F.; Djurovic, M.; Isajlovic, I.; Jadaud, A.; et al. Spatial variability of Chondrichthyes in the northern Mediterranean. Sci. Mar. 2019, 83S1, 81-100. [CrossRef]

12. Devine, J.A.; Baker, K.D.; Haedrich, R.L. Deep-sea fishes qualify as endangered. Nature 2006, 439, 29. [CrossRef] [PubMed]

13. Massutí, E.; Moranta, J. Demersal assemblages and depth distribution of elasmobranchs from the continental shelf and slope off the Balearic Islands (Western Mediterranean). ICES J. Mar. Sci. 2003, 60, 753-766. [CrossRef]

14. Sion, L.; Bozzano, A.; D’Onghia, G.; Capezzuto, F.; Panza, M. Chondrichthyes species in deep waters of the Mediterranean Sea. Sci. Mar. 2004, 68, 153-162. [CrossRef]

15. Ragonese, S.; Vitale, S.; Dimech, M.; Mazzola, S. Abundances of demersal sharks and chimaera from 1994-2009 scientific surveys in the Central Mediterranean Sea. PLoS ONE 2013, 8, e74865. [CrossRef] [PubMed]

16. Marongiu, M.F.; Porcu, C.; Bellodi, A.; Cannas, R.; Cau, A.; Cuccu, D.; Mulas, A.; Follesa, M.C. Temporal dynamics of demersal chondrichthyan species in the Central Western Mediterranean Sea: The case study in Sardinia Island. Fish. Res. 2017, 193, 81-94. [CrossRef]

17. Pikitch, E.K.; Chapman, D.D.; Babcock, E.A.; Shivji, M.S. Habitat use and demographic population structure of elasmobranchs at a Caribbean atoll (Glover's Reef, Belize). Mar. Ecol. Prog. Ser. 2005, 302, 187-197. [CrossRef]

18. Worm, B.; Davis, B.; Kettemer, L.; Ward-Paige, C.A.; Chapman, D.; Heithaus, M.R.; Kessel, S.T.; Gruber, S.H. global catches, exploitation rates, and rebuilding options for sharks. Mar. Policy 2013, 40, 194-204. [CrossRef]

19. Simpfendorfer, C.A.; Hueter, R.E.; Bergman, U.; Connett, S.M.H. Results of a fishery-independent survey for pelagic sharks in the Western North Atlantic, 1977-1994. Fish. Res. 2002, 55, 175-192. [CrossRef]

20. Baum, J.K.; Blanchard, W. Inferring Shark Population Trends from generalized linear mixed models of pelagic longline catch and effort data. Fish. Res. 2010, 102, 229-239. [CrossRef]

21. Santana-Garcon, J.; Braccini, M.; Langlois, T.J.; Newman, S.J.; McAuley, R.B.; Harvey, E.S. Calibration of pelagic stereo-bruvs and scientific longline surveys for sampling sharks. Methods Ecol. Evol. 2014, 5, 824-833. [CrossRef]

22. Andrews, K.S.; Williams, G.D.; Farrer, D.; Tolimieri, N.; Harvey, C.J.; Bargmann, G.; Levin, P.S. Diel Activity patterns of sixgill sharks, Hexanchus griseus: The Ups and Downs of an Apex Predator. Anim. Behav. 2009, 78, 525-536. [CrossRef]

23. Rodríguez-Cabello, C.; Sánchez, F. Catch and post-release mortalities of deep-water sharks caught by bottom longlines in the Cantabrian Sea (NE Atlantic). J. Sea Res. 2017, 130, 248-255. [CrossRef]

24. Brooks, E.J.; Mandelman, J.W.; Sloman, K.A.; Liss, S.; Danylchuk, A.J.; Cooke, S.J.; Skomal, G.B.; Philipp, D.P.; Sims, D.W.; Suski, C.D. The Physiological response of the caribbean reef shark (Carcharhinus perezi) to longline capture. Comp. Biochem. Physiol. A Mol. Integr. Physiol. 2012, 162, 94-100. [CrossRef]

25. Skomal, G.B. Evaluating the physiological and physical consequences of capture on post-release survivorship in large pelagic fishes. Fish. Manag. Ecol. 2007, 14, 81-89. [CrossRef] 
26. Malcolm, H.A.; Gladstone, W.; Lindfield, S.; Wraith, J.; Lynch, T.P. Spatial and temporal variation in reef fish assemblages of marine parks in New South Wales, Australia-baited video observations. Mar. Ecol. Prog. Ser. 2007, 350, 277-290. [CrossRef]

27. Brooks, E.J.; Sloman, K.A.; Sims, D.W.; Danylchuk, A.J. Validating the use of baited remote underwater video surveys for assessing the diversity, distribution and abundance of sharks in the Bahamas. Endanger. Species Res. 2011, 13, 231-243. [CrossRef]

28. White, J.; Simpfendorfer, C.A.; Tobin, A.J.; Heupel, M.R. Application of baited remote underwater video surveys to quantify spatial distribution of elasmobranchs at an ecosystem scale. J. Exp. Mar. Biol. Ecol. 2013, 448, 281-288. [CrossRef]

29. McLean, D.L. Comparison of baited longlines and baited underwater cameras for assessing the composition of continental slope deepwater fish assemblages off Southeast Australia. Deep Sea Res. Part I Oceanogr. Res. Pap. 2015, 98, 10-20. [CrossRef]

30. Devine, B.M.; Wheeland, L.J.; Fisher, J.A.D. First Estimates of Greenland shark (Somniosus microcephalus) local abundances in arctic waters. Sci. Rep. 2018, 8, 974. [CrossRef]

31. Pimentel, C.R.; Andrades, R.; Ferreira, C.E.L.; Gadig, O.B.F.; Harvey, E.S.; Joyeux, J.; Giarrizzo, T. BRUVS Reveal locally extinct shark and the way for shark monitoring in brazilian oceanic islands. J. Fish Biol. 2020, 96, 539-542. [CrossRef]

32. Osgood, G.J.; McCord, M.E.; Baum, J.K. Using Baited Remote Underwater Videos (BRUVs) to characterize chondrichthyan communities in a global biodiversity hotspot. PLoS ONE 2019, 14, e0225859. [CrossRef] [PubMed]

33. Söffker, M.; Sloman, K.A.; Hall-Spencer, J.M. In situ observations of fish associated with coral reefs off Ireland. Deep Sea Res. Part I Oceanogr. Res. Pap. 2011, 58, 818-825. [CrossRef]

34. D’Onghia, G.; Capezzuto, F.; Carluccio, A.; Carlucci, R.; Giove, A.; Mastrototaro, F.; Panza, M.; Sion, L.; Tursi, A.; Maiorano, P. Exploring composition and behaviour of fish fauna by in situ observations in the Bari Canyon (Southern Adriatic Sea, Central Mediterranean). Mar. Ecol. 2015, 36, 541-556. [CrossRef]

35. D’Onghia, G.; Capezzuto, F.; Cardone, F.; Carlucci, R.; Carluccio, A.; Chimienti, G.; Corriero, G.; Longo, C.; Maiorano, P.; Mastrototaro, F.; et al. Macro- and megafauna recorded in the submarine Bari Canyon (Southern Adriatic, Mediterranean Sea) using different tools. Mediterr. Mar. Sci. 2015, 16, 180. [CrossRef]

36. Capezzuto, F.; Maiorano, P.; Panza, M.; Indennidate, A.; Sion, L.; D'Onghia, G. Occurrence and behaviour of Paromola cuvieri (Crustacea, Decapoda) in the Santa Maria Di Leuca cold-water coral community (Mediterranean Sea). Deep Sea Res. Part I Oceanogr. Res. Pap. 2012, 59, 1-7. [CrossRef]

37. Yeh, J.; Drazen, J. Baited-Camera observations of deep-sea megafaunal scavenger ecology on the California slope. Mar. Ecol. Prog. Ser. 2011, 424, 145-156. [CrossRef]

38. Harvey, E.S.; Newman, S.J.; McLean, D.L.; Cappo, M.; Meeuwig, J.J.; Skepper, C.L. Comparison of the relative efficiencies of stereo-BRUVs and traps for sampling tropical continental shelf demersal fishes. Fish. Res. 2012, 125-126, 108-120. [CrossRef]

39. Capezzuto, F.; Calculli, C.; Carlucci, R.; Carluccio, A.; Maiorano, P.; Pollice, A.; Sion, L.; Tursi, A.; D'Onghia, G. Revealing the Coral habitat effect on benthopelagic fauna diversity in the Santa Maria Di Leuca Cold-water coral province using different devices and bayesian hierarchical modelling. Aquat. Conserv. Mar. Freshw. Ecosyst. 2019, 29, 1608-1622. [CrossRef]

40. Ayma, A.; Aguzzi, J.; Canals, M.; Lastras, G.; Bahamon, N.; Mecho, A.; Company, J.B. Comparison between ROV video and Agassiz trawl methods for sampling deep water fauna of submarine canyons in the Northwestern Mediterranean Sea with observations on behavioural reactions of target species. Deep Sea Res. Part I Oceanogr. Res. Pap. 2016, 114, 149-159. [CrossRef]

41. Cappo, M.; Speare, P.; De'ath, G. Comparison of baited remote underwater video stations (BRUVS) and prawn (shrimp) trawls for assessments of fish biodiversity in inter-reefal areas of the Great Barrier Reef Marine Park. J. Exp. Mar. Biol. Ecol. 2004, 302, 123-152. [CrossRef]

42. Dulvy, N.K.; Allen, D.; Ralph, G.; Walls, R. The Conservation Status of Sharks, Rays and Chimaeras in the Mediterranean Sea; IUCN: Malaga, Spain, 2016; p. 14.

43. Dulvy, N.K.; Fowler, S.L.; Musick, J.A.; Cavanagh, R.D.; Kyne, M.; Harrison, L.R.; Carlson, J.K.; Davidson, L.N.; Francis, M.P.; Pollock, C.M.; et al. Extinction risk and conservation of the world's sharks and rays. eLife 2014, 3, e00590. [CrossRef] [PubMed]

44. Colloca, F.; Enea, M.; Ragonese, S.; Di Loreno, M. A century fishery data documenting the collapse of smooth-hounds (Mustelus spp.) in Mediterranean Sea. Aquat. Conserv. 2017, 27, 1145-1155. [CrossRef]

45. Pacoureau, N.; Rigby, C.L.; Kyne, P.M.; Sherley, R.B.; Winker, H.; Carlson, J.K.; Fordham, S.V.; Barreto, R.; Fernando, D.; Francis, M.P.; et al. Half a century of global decline in oceanic sharks and rays. Nature 2021, 589, 567-571. [CrossRef] [PubMed]

46. Barausse, A.; Correale, V.; Curkovic, A.; Finotto, L.; Riginella, E.; Visentin, E.; Mazzoldi, C. The role of fisheries and the environment in driving the decline of elasmobranchs in the Northern Adriatic Sea. ICES J. Mar. Sci. 2014, 71, 1593-1603. [CrossRef]

47. D'Onghia, G.; Sion, L.; Capezzuto, F. Cold-water coral habitats benefit adjacent fisheries along the Apulian margin (Central Mediterranean). Fish. Res. 2019, 213, 172-179. [CrossRef]

48. Trincardi, F.; Foglini, F.; Verdicchio, G.; Asioli, A.; Correggiari, A.; Minisini, D.; Piva, A.; Remia, A.; Ridente, D.; Taviani, M. The Impact of cascading currents on the Bari Canyon system, SW-Adriatic Margin (Central Mediterranean). Mar. Geol. 2007, 246, 208-230. [CrossRef]

49. Ridente, D.; Foglini, F.; Minisini, D.; Trincardi, F.; Verdicchio, G. Shelf-edge erosion, sediment failure and inception of Bari Canyon on the Southwestern Adriatic Margin (Central Mediterranean). Mar. Geol. 2007, 246, 193-207. [CrossRef]

50. Chimienti, G.; Bo, M.; Taviani, M.; Mastrototaro, F. Occurrence and biogeography of Mediterranean cold-water corals. In Mediterranean Cold-Water Corals: Past, Present and Future; Orejas, C., Jiménez, C., Eds.; Springer International Publishing AG: Berlin/ Heidelberg, Germany, 2019; Volume 9, pp. 295-333. 
51. D’Onghia, G.; Calculli, C.; Capezzuto, F.; Carlucci, R.; Carluccio, A.; Maiorano, P.; Pollice, A.; Ricci, P.; Sion, L.; Tursi, A. New records of cold-water coral sites and fish fauna characterization of a potential network existing in the Mediterranean Sea. Mar. Ecol. 2016, 37, 1398-1422. [CrossRef]

52. Taviani, M.; Angeletti, L.; Canese, S.; Cannas, R.; Cardone, F.; Cau, A.; Cau, A.B.; Follesa, M.C.; Marchese, F.; Montagna, P.; et al. The "Sardinian cold-water coral province" in the context of the Mediterranean coral ecosystems. Deep Sea Res. Part II Top. Stud. Oceanogr. 2017, 145, 61-78. [CrossRef]

53. Freiwald, A.; Beuck, L.; Ruggerberg, A.; Taviani, M.; Hebblen, D. The white coral community in the Central Mediterranean Sea revealed by ROV surveys. Oceanography 2009, 22, 36-52. [CrossRef]

54. Turchetto, M.; Boldrin, A.; Langone, L.; Miserocchi, S.; Tesi, T.; Foglini, F. Particle transport in the Bari Canyon (Southern Adriatic Sea). Mar. Geol. 2007, 246, 231-247. [CrossRef]

55. Angeletti, L.; Taviani, M.; Canese, S.; Foglini, F.; Mastrototaro, F.; Argnani, A.; Trincardi, F.; Bakran-Petricioli, T.; Ceregato, A.; Chimienti, G.; et al. New Deep-Water cnidarian sites in the Southern Adriatic Sea. Mediterr. Mar. Sci. 2014, 15, 263. [CrossRef]

56. Sion, L.; Calculli, C.; Capezzuto, F.; Carlucci, R.; Carluccio, A.; Cornacchia, L.; Maiorano, P.; Pollice, A.; Ricci, P.; Tursi, A.; et al. Does the Bari Canyon (Central Mediterranean) influence the fish distribution and abundance? Prog. Oceanogr. 2019, 170, 81-92. [CrossRef]

57. Mastrototaro, F.; D’Onghia, G.; Corriero, G.; Matarrese, A.; Maiorano, P.; Panetta, P.; Gherardi, M.; Longo, C.; Rosso, A.; Sciuto, F.; et al. Biodiversity of the white coral bank off Cape Santa Maria Di Leuca (Mediterranean Sea): An update. Deep Sea Res. Part II Top. Stud. Oceanogr. 2010, 57, 412-430. [CrossRef]

58. Savini, A.; Vertino, A.; Marchese, F.; Beuck, L.; Freiwald, A. Mapping cold-water coral habitats at different scales within the Northern Ionian Sea (Central Mediterranean): An assessment of coral coverage and associated vulnerability. PLoS ONE 2014, 9, e87108. [CrossRef] [PubMed]

59. Tursi, A.; Mastrototaro, F.; Matarrese, A.; Maiorano, P.; D'Onghia, G. Biodiversity of the white coral reefs in the Ionian Sea (Central Mediterranean). Chem. Ecol. 2004, 20, 107-116. [CrossRef]

60. D'Onghia, G.; Maiorano, P.; Sion, L.; Giove, A.; Capezzuto, F.; Carlucci, R.; Tursi, A. Effects of deep-water coral banks on the abundance and size structure of the megafauna in the Mediterranean Sea. Deep Sea Res. Part II Top. Stud. Oceanogr. 2010, 57, 397-411. [CrossRef]

61. D'Onghia, G.; Maiorano, P.; Carlucci, R.; Capezzuto, F.; Carluccio, A.; Tursi, A.; Sion, L. Comparing Deep-sea fish fauna between coral and non-coral "megahabitats" in the Santa Maria Di Leuca cold-water coral province (Mediterranean Sea). PLoS ONE 2012, 7, e44509. [CrossRef]

62. D'Onghia, G.; Capezzuto, F.; Carlucci, R.; Carluccio, A.; Maiorano, P.; Panza, M.; Ricci, P.; Sion, L.; Tursi, A. Using a benthic lander to explore and monitor vulnerable ecosystems in the Mediterranean Sea. ACTA IMEKO 2018, 7, 45. [CrossRef]

63. Magurran, A. Ecological Diversity and Its Measurement. Princeton University Press: Princeton, NJ, USA, 1991; 178p.

64. Colwell, R.K.; Chao, A.; Gotelli, N.J.; Lin, S.-Y.; Mao, C.X.; Chazdon, R.L.; Longino, J.T. Models and Estimators Linking Individual-Based and Sample-Based Rarefaction, Extrapolation and Comparison of Assemblages. J. Plant Ecol. 2012, 5, 3-21. [CrossRef]

65. Brown, S.C.; Bizzarro, J.J.; Cailliet, G.M.; Ebert, D.A. Breaking with Tradition: Redefining Measures for Diet Description with a Case Study of the Aleutian Skate Bathyraja aleutica (Gilbert 1896). Environ. Biol. Fishes 2012, 95, 3-20. [CrossRef]

66. Clarke, K.R. Non-parametric multivariate analyses of changes in community structure. Austral Ecol. 1993, 18, 117-143. [CrossRef]

67. Anderson, M.J. A New method for non-parametric multivariate analysis of variance: Non-parametric manova for ecology. Austral Ecol. 2001, 26, 32-46. [CrossRef]

68. Dufrêne, M.; Legendre, P. Species assemblages and indicator species: The need for a flexible asymmetrical approach. Ecol. Monogr. 1997, 67, 345-366. [CrossRef]

69. Hammer, O.; Harper, D.A.T.; Ryan, P.D. PAST: Paleontological statistics software package for education and data analysis. Palaeontol. Electron. 2001, 4, 1-9.

70. Clarke, K.; Gorley, R.N. Primer v6: User Manual/Tutorial; PRIMER-E: Plymouth, UK, 2006.

71. Anderson, M.J.; Gorley, R.N.; Clarke, K.R. PERMANOVA+ for PRIMER: Guide to Software and Statistical Methods; PRIMER-E: Plymouth, UK, 2008.

72. Spedicato, M.T.; Massutí, E.; Merigot, B.; Tserpes, G.; Jadaud, A.; Relini, G. The MEDITS trawl survey specifications in an ecosystem approach to fishery management. Sci. Mar. 2019, 83, 9-20. [CrossRef]

73. Bozzano, A.; Murgia, R.; Vallerga, S.; Hirano, J.; Archer, S. The Photoreceptor System in the Retinae of Two Dogfishes, Scyliorhinus canicula and Galeus melastomus: Possible Relationship with Depth Distribution and Predatory Lifestyle. J. Fish Biol. 2001, 59, 1258-1278. [CrossRef]

74. Navarro, J.; López, L.; Coll, M.; Barría, C.; Saez-Liante, R. Short- and Long- term Importance of Small Sharks in the Diet of the Rare Deep Sea Shark Dalatia licha. Mar. Biol. 2014, 161, 1697-1707. [CrossRef]

75. Tursi, A.; D'Onghia, G.; Matarrese, A.; Piscitelli, G. Observations on population biology of Galeus melastomus Rafinesque, 1810 (CHONDRICHTHYES, SCYLIORHINIDAE) in the Ionian Sea. Cybium 1993, 17, 187-196.

76. Ricci, P.; Sion, L.; Capezzuto, F.; Cipriano, G.; D’Onghia, G.; Libralato, S.; Maiorano, P.; Tursi, A.; Carlucci, R. Modelling the trophic roles of the demersal Chondrichthyes in the Northern Ionian Sea (Central Mediterranean Sea). Ecol. Model. 2021, $444,109468$. [CrossRef] 
77. Megalofonou, P.; Chatzispyrou, A. Sexual Maturity and Feeding of the Gulper Shark, Centrophorus granulosus, from the Eastern Mediterranean Sea. Cybium 2006, 30, 67-74.

78. Guallart, J.; Vicent, J.J. Changes in Composition During Embryo Development of the Gulper Shark, Centrophorus granulosus (Elasmobranchii, Centrophoridae): An Assessment of Maternal-Embryonic Nutritional Relationships. Environ. Biol. Fishes 2001, 61, 135-150. [CrossRef]

79. Metochis, C.P.; Carmona-Antoñanzas, G.; Kousteni, V.; Damalas, D.; Megalofonou, P. Population Structure and Aspects of the Reproductive Biology of the Blackmouth Catshark, Galeus Melastomus Rafinesque, 1810 (Chondrichthyes: Scyliorhinidae) Caught Accidentally off the Greek Coasts. J. Mar. Biol. Assoc. U. K. 2018, 98, 909-925. [CrossRef]

80. D'Iglio, C.; Savoca, S.; Rinelli, P.; Spanò, N.; Capillo, G. Diet of the Deep-Sea Shark Galeus Melastomus Rafinesque, 1810, in the Mediterranean Sea: What We Know and What We Should Know. Sustainability 2021, 13, 3962. [CrossRef]

81. Dulvy, N.K.; Reynolds, J.D. Predicting extinction vulnerability in skates. Conserv. Biol. 2002, 16, 440-450. [CrossRef]

82. Flowers, K.I.; Ajemian, M.J.; Bassos-Hull, K.; Feldheim, K.A.; Hueter, R.E.; Papastamatiou, Y.P.; Chapman, D.D. A review of batoid philopatry, with implications for future research and population management. Mar. Ecol. Prog. Ser. 2016, 562, $251-261$. [CrossRef]

83. Capezzuto, F.; Ancona, F.; Carlucci, R.; Carluccio, A.; Cornacchia, L.; Maiorano, P.; Ricci, P.; Sion, L.; Tursi, A.; D’Onghia, G. Cold-Water Coral Communities in the Central Mediterranean: Aspects on Megafauna Diversity, Fishery Resources and Conservation Perspectives. Rend. Lincei Sci. Fis. Nat. 2018, 29, 589-597. [CrossRef]

84. GFCM-RAC/SPA. In Report of the Transversal Workshop on Marine Protected Areas (MPAs); FAO: Salammbo, Tunisia, 2007.

85. Angeletti, L.; D'Onghia, G.; Otero, M.d.M.; Settanni, A.; Spedicato, M.T.; Taviani, M. A Perspective for Best Governance of the Bari Canyon Deep-Sea Ecosystems. Water 2021, 13, 1646. [CrossRef] 